\title{
ESTIMATION OF TIDAL ENERGY DISSIPATION AND DIAPYCNAL DIFFUSIVITY IN THE INDONESIAN SEAS
}

\author{
I Wayan Gede Astawa Karang ${ }^{1,2,3}$, Fumihiko Nishio ${ }^{1,3}$ And Takahiro Osawa ${ }^{2}$
}

\begin{abstract}
The Indonesian Seas separating the Indian Ocean from the West Pacific Ocean are representative regions of strong tidal mixing in the world oceans. In the present study, we first carry out numerical simulation of the barotropic tidal elevation field in the Indonesian Seas using horizontally two-dimensional primitive equation model. It is found that, to reproduce realistic tidal elevations in the Indonesian Seas, the energy lost by the incoming barotropic tides to internal waves within the Indonesian seas should be taken into account. The numerical experiments show that the model predicted tidal elevations in the Indonesian Seas best fit the observed data when we take into account the baroclinic energy conversion in the Indonesian Seas $\sim 86.1 \mathrm{GW}$ for the $\mathrm{M}_{2}$ tidal constituent and $\sim 134.6 \mathrm{GW}$ for the major four tidal constituents $\left(\mathrm{M}_{2}, \mathrm{~S}_{2}, \mathrm{~K}_{1}, \mathrm{O}_{1}\right)$. For this baroclinic energy conversion, the value of $K \rho$ averaged within the eastern area (Halmahera, Seram, Banda and Maluku Seas), the western area (Makassar and Flores Seas), and the southern area (Lombok Strait and Timor Passage) are estimated to be $\sim 23 \times 10^{-4} \mathrm{~m}^{2} \mathrm{~s}^{-1}, \sim 5 \times 10^{-4} \mathrm{~m}^{2} \mathrm{~s}^{-1}$, and $\sim 10 \times 10^{-4}$ $\mathrm{m}^{2} \mathrm{~s}^{-1}$, respectively. This value is about 1 order of magnitude more than assumed for the Indonesian Seas in previous ocean general circulation models. We offer this study as a warning against using diapycnal diffusivity just as a tuning parameter to reproduce largescale phenomena.
\end{abstract}

Keywords: Baroclinic energy conversion, barotropic tides, diapycnal diffusivity, Indonesian Seas, internal waves, tidal elevations

\section{Introduction}

The Indonesian Seas are among the most significant generation regions of the internal tide in the world's oceans. The area is characterized by strong barotropic tidal currents [Hatayama, 1996] as well as prominent topographic features and 20-150 GW of M2 barotropic to baroclinic energy conversion is expected to occur [Niwa and Hibiya, 2001; Egbert and Ray, 2001; Simmons et al., 2004; Larrouy et al., 2007]. Internal tides generated by tide-topography interactions then break causing vigorous diapycnal mixing. Indeed, using an

\footnotetext{
1 Center for Environmental Remote Sensing, Chiba University, Japan

2 CReSOS, Udayana University, Denpasar, Bali

3. Graduate School of Sciences, Department of Earth Sciences, Chiba University, Japan
}

advection-diffusion model and archived data, a large diapycnal diffusivity exceeding $1 \times 10-4 \mathrm{~m} 2 \mathrm{~s}-1$ is inferred for the Indonesian thermocline [Ffield and Gordon, 1992; Gordon, 1986].

The transformation of water mass properties taking place in the Indonesian Seas is important not only for local phenomena but also for global ocean heat and mass budgets. The Indonesian Throughflow (ITF) connects the main thermocline waters in the Pacific and Indian Oceans. The ITF transports relatively warm, 
low salinity thermocline water from the western Pacific Ocean through the multitude of the Indonesian Seas and straits, to the Indian Ocean [Gordon, 1986; Hirst and Godfrey, 1993; Miyama et al., 1995; Schiller et al., 1998]. Diapycnal mixing within the Indonesian Seas significantly alters the thermohaline stratification and the velocity profile of the ITF [Ffield and Gordon, 1992; Gordon et al., 1994]. For example, as the ITF carries North Pacific thermocline water from the Sulawesi Sea to the Makassar Strait and Flores Sea, then to the Banda Sea and Timor Sea, the salinity minimum at $300 \mathrm{db}$ are greatly attenuated [Ffield and Gordon, 1992]. Water mass transformation in the Indonesian Seas then affects global ocean circulation. For example, Schiller et al. [1998] carried out a numerical experiment using an ocean general circulation model to show that temperature and salinity distributions in the Indian Ocean are subject to large diapycnal diffusivity in the Indonesian Seas [Ffield and Gordon, 1996].

Although vigorous diapycnal mixing in the Indonesian Seas is thus an important physical process, quantitative estimates of its intensity have not been carried out. The tidal energy available for mixing processes has also not yet been reliably determined [Ray et al., 2005]. Although Hatayama [2004] carried out vertically twodimensional numerical experiments to demonstrate that breaking of large amplitude internal waves at Dewakang Sill in the southern Makassar Strait can produce large diapycnal diffusivity $\sim 60 \times 10-4 \mathrm{~m} 2 \mathrm{~s}-$ 1 , spatial distribution of "mixing hot spots" in the Indonesian Seas has not been clarified yet.

In the present study, we first show that, to reproduce realistic tidal elevations in the Indonesian Seas and surrounding region, the energy lost by incoming barotropic tides to internal waves within the Indonesia Seas should be taken into account. Next, the diapycnal diffusivity in the Indonesian Seas is quantitatively estimated in terms of the model predicted baroclinic energy conversion. In this study, we mainly focus on the most dominant M2 tidal constituent [Hatayama et al., 1996], although the results of numerical experiments for other major tidal constituents ( $\mathrm{K} 1, \mathrm{O} 1$, and $\mathrm{S} 2)$ are also discussed briefly.

\section{Numerical Experiments}

The model region in this study extends from $92 \mathrm{oE}$ to $142 \mathrm{oE}$ in longitudinal direction and from $20 \mathrm{oS}$ to $23 \mathrm{oN}$ in latitudinal direction (Figure 1). This covers the entire Indonesian Seas and surrounding region. The open boundaries are assumed sufficiently away from the Indonesian Seas to prevent the tidal field in the Indonesian Seas from being disturbed by the reflected waves from the open boundaries. 


\section{(deg)}

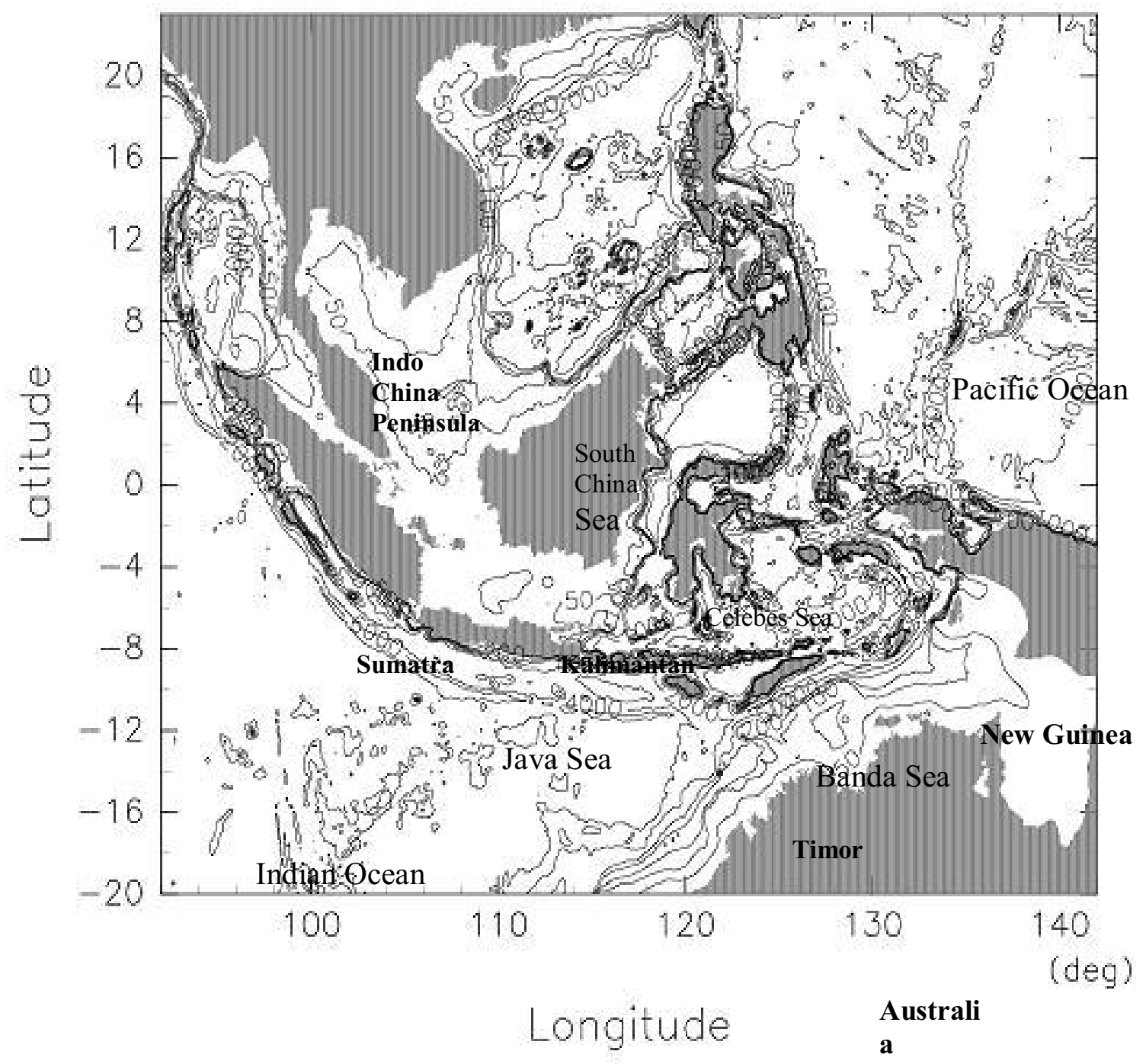

Figure 1. Model domain and bathymetry including the Indian Ocean and adjacent seas. Contours of the bathymetry are 50,100, 200,500,1000, 2000, 4000, and $6000 \mathrm{~m}$, respectively. 
The governing equations are the horizontally two-dimensional, depthintegrated Navier-Stokes equations in Cartesians coordinate system given by

$$
\begin{aligned}
& \frac{\partial \eta}{\partial t}+\frac{\partial}{\partial x}(u D)+\frac{\partial}{\partial y}(v D)=0 \\
& \frac{\partial}{\partial t}(u D)+\frac{\partial}{\partial x}\left(u^{2} D\right)+\frac{\partial}{\partial y}(u v D) \quad f v D \\
& =g D \frac{\partial}{\partial x}\left(\eta-\eta_{S A L}-\beta \zeta\right)-C_{d}|\overline{\mathbf{u}}| u+F_{x} \\
& \frac{\partial}{\partial t}(v D)+\frac{\partial}{\partial x}(u v D)+\frac{\partial}{\partial y}\left(v^{2} D\right)+f u D \\
& \quad g D \frac{\partial}{\partial y}\left(\eta-\eta_{S A L}-\beta \zeta\right)-C_{d}|\overline{\mathbf{u}}| v+F_{y}
\end{aligned}
$$

where $t$ is time; $x$ and $y$ are defined positive eastward and northward, respectively; $u$ and $v$ are the depthaveraged velocities in the $x$ and $y$ directions, respectively; $f=2: \sin \varphi$ is the Coriolis frequency with : the angular velocity of the Earth's rotation and $\varphi$ latitude; $g$ is the acceleration due to gravity; $\eta$ is the free surface elevation; $\mathrm{D}=\mathrm{H}+\eta$ with $\mathrm{H}$ the local ocean depth; $\zeta$ is the forcing equilibrium tide; $\beta$ multiplying $\zeta$ is the effective Earth elasticity which is assumed to be 0.693 for the $\mathrm{M}_{2}$ and 0.736 for the $\mathrm{K}_{1}$ tidal constituent following Kantha [1995]; $\eta_{S A L}$ is self-attraction/loading term induced by ocean tide which was calculated from the global ocean tidal model by Matsumoto et al. [2000]. The bottom stress is parameterized using quadratic law with a bottom drag coefficient $C_{d}=0.0025 . F_{x}$ and $F_{y}$ are horizontal viscosity terms given by

$$
F_{x}=\frac{\partial}{\partial x}\left[2 H A_{H} \frac{\partial u}{\partial x}\right]+\frac{\partial}{\partial y}\left[H A_{H}\left(\frac{\partial u}{\partial y}+\frac{\partial v}{\partial x}\right)\right]
$$

$$
F_{y}=\frac{\partial}{\partial y}\left[2 H A_{H} \frac{\partial v}{\partial y}\right]+\frac{\partial}{\partial x}\left[H A_{H}\left(\frac{\partial u}{\partial y}+\frac{\partial v}{\partial x}\right)\right]
$$

with $A_{H}$ the horizontal eddy viscosity coefficient determined following Smagorinsky [1963].

The governing equations (1)-(3) are numerically solved using a finite difference method. The grid size is $(1 / 15)^{\circ}$ both in the longitudinal and latidunal directions. The model topography is obtained by averaging the bathymetric data from "GEBCO" within a $10 \mathrm{~km}$ radius at each grid point.

[10] A slip boundary condition is assumed along the land boundaries. At the open boundaries, tidal elevations are specified on the basis of the calculated results of Matsumoto et al. [2000]. The model is thus driven by these boundaries forcing as well as tidal potential forcing.

The model is driven for 15 days from an initial state at rest for semidiurnal and diurnal tides, by which time the model ocean attains quasistationary oscillations. The calculated time series for the final four tidal periods are harmonically analyzed to obtain the amplitude and phase of each tidal constituent. For the energy balance calculation, the data averaged over final one tidal period is used.

\section{Tidal Elevation Field in the Indonesian Seas}

Coamplitude and cophase charts for the $\mathrm{M}_{2}$ tidal constituent are given in Figure 2 and 3 , respectively. The spatial patterns of coamplitude and cophase charts are qualitatively consistent with those from previous numerical studies [Hatayama et al., 1996; Ray et al., 2005]. 


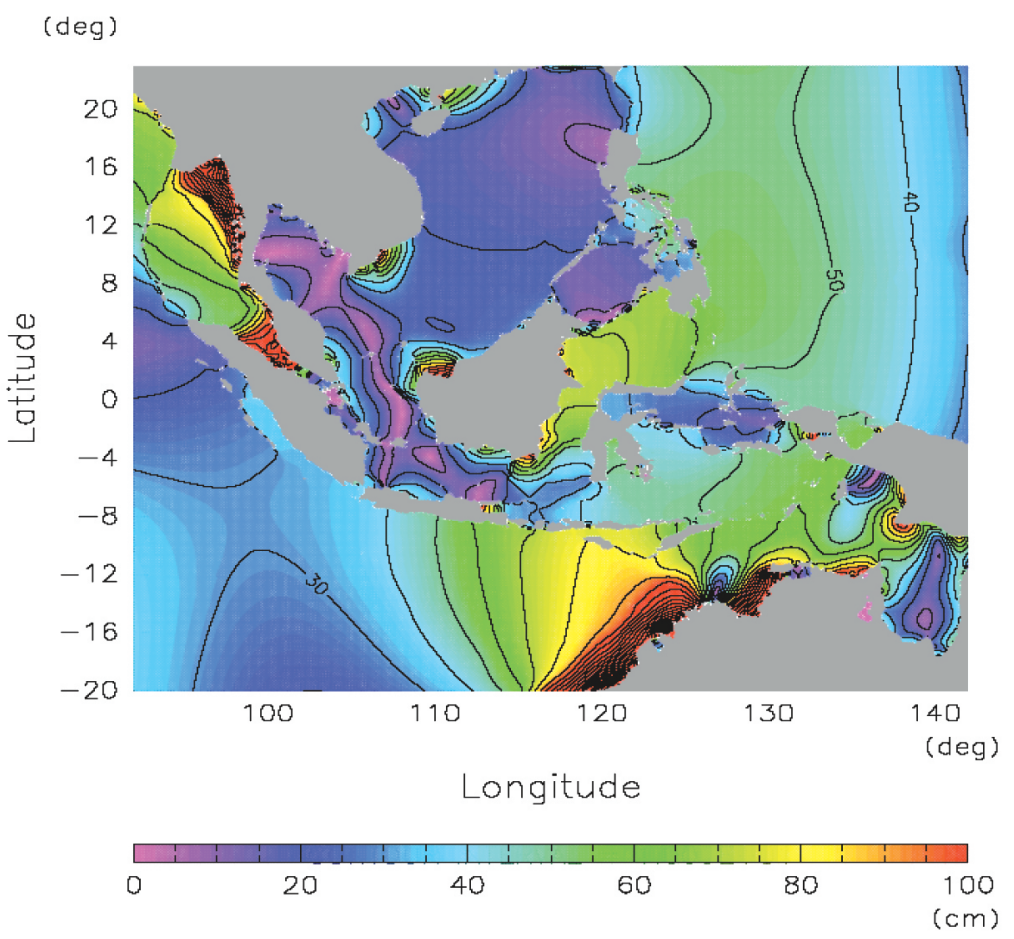

Figure 2. Calculated coamplitude chart of tidal elevations for the $\mathrm{M}_{2}$ tide (interval is $5 \mathrm{~cm}$ ).
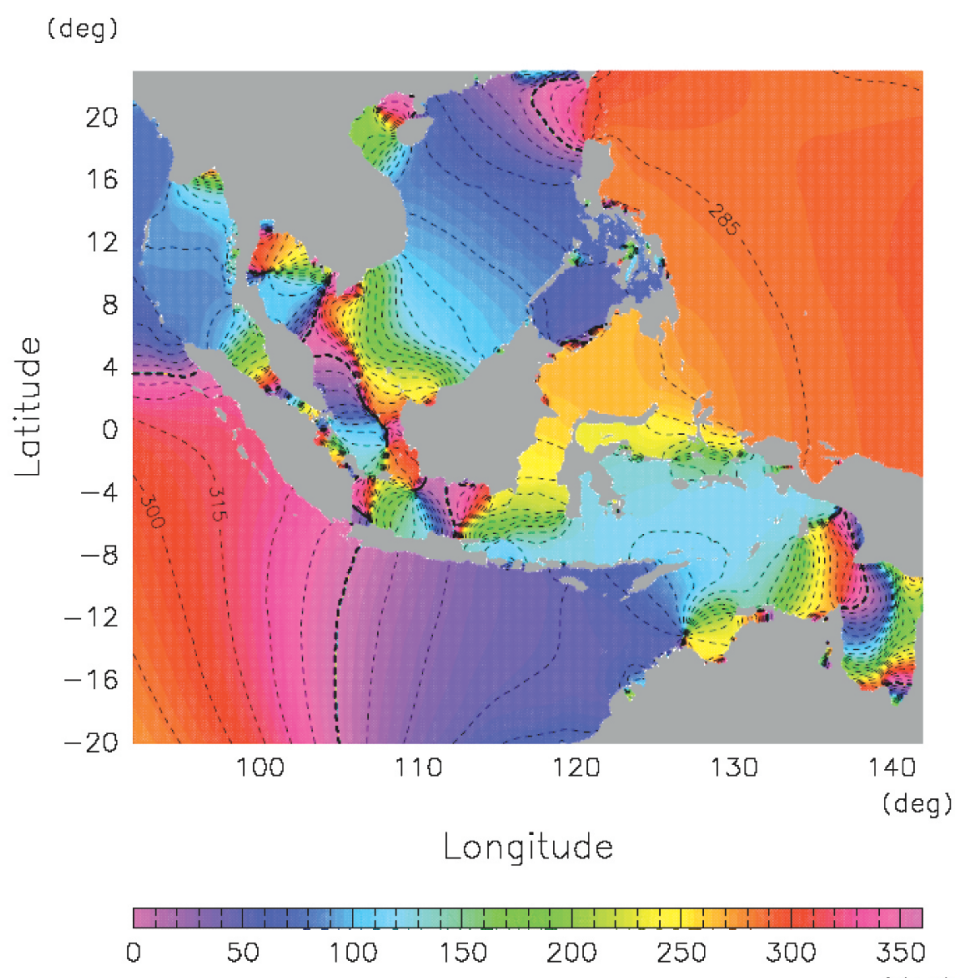

Figure 3. Calculated cophase chart of tidal elevations for the $\mathrm{M}_{2}$ tide. The contour interval is 15 degree. The phases are referred to Greenwich. 
The $\mathrm{M}_{2}$ tide response is clearly dominated by the large tide from the Indian Ocean, where amplitudes are well over one meter off northwest Australia. This wave is delayed slightly (about 2 hours) as it passes into the Banda and Flores Seas. Those seas are sufficiently deep that high tide occurs almost simultaneously throughout both basins. From the Banda Sea, the $\mathrm{M}_{2}$ tide passes slowly northwards through the Molucca Sea region. From the Flores Sea, it propagates slowly northwards into Makassar Strait and westwards across the Java Sea.

The calculated tidal elevations are now compared with the observed data. The observed data used here are tidal harmonic data from international coastal tide gauges records provided by $K$. Matsumoto and Department Earth and Planetary Science, University of Tokyo. Figure 4 shows the spatial distributions of the tide gauges stations in Indonesian Seas and adjacent areas. The observed data were taken from
174 coastal tide gauge stations for the major four tidal constituents $\left(\mathrm{M}_{2}, \mathrm{~S}_{2}, \mathrm{~K}_{1}\right.$, $\mathrm{O}_{1}$ ). The names and locations of each station are described in appendix. We calculate the root mean-square (RMS) difference defined as

$$
\text { RMS } \frac{1}{\mathrm{~T}}\left\{\int_{0}^{\mathrm{T}}\left[\eta_{\mathrm{obs}} \cos \left(\omega t-\theta_{\text {obs }}\right)-\eta_{\bmod } \cos \left(\omega t+\theta_{\bmod }\right)\right]^{2} \mathrm{dt}\right\}^{1 / 2}
$$

where $\mathrm{T}$ is the tidal period; $\omega$ is the frequency; $\eta$ and $\theta$ are the amplitude and the phase, respectively; and subscripts $o b s$ and mod represent the observed and calculated harmonic constants, respectively. Figure 5 shows the RMS difference between the calculated and observed tidal elevations. The RMS difference between the models predicted tidal elevations and observed data in the Indonesian Seas averages at $11.18 \mathrm{~cm}$. This value is almost the same as those of previous numerical studies (for example, the average of RMS difference of Hatayama et al. [1996] is $11.2 \mathrm{~cm}$ ).

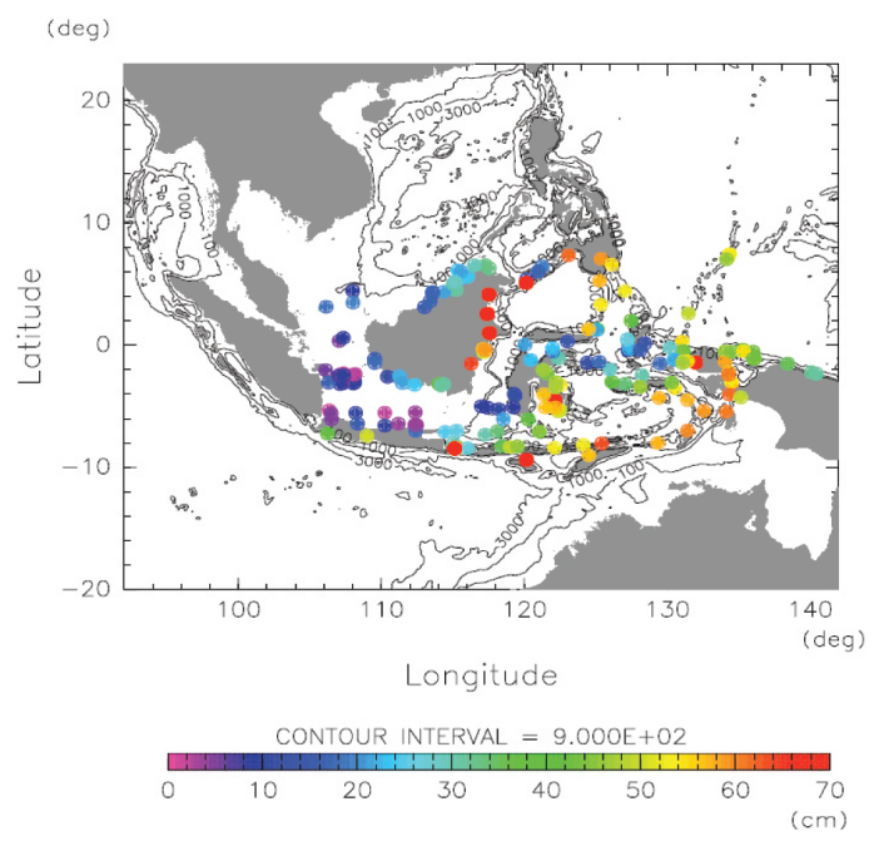

Figure 4. Spatial distribution of tides gauges station in the study area. The color scale shows the amplitude of $\mathrm{M}_{2}$ tidal constituent for each station. 


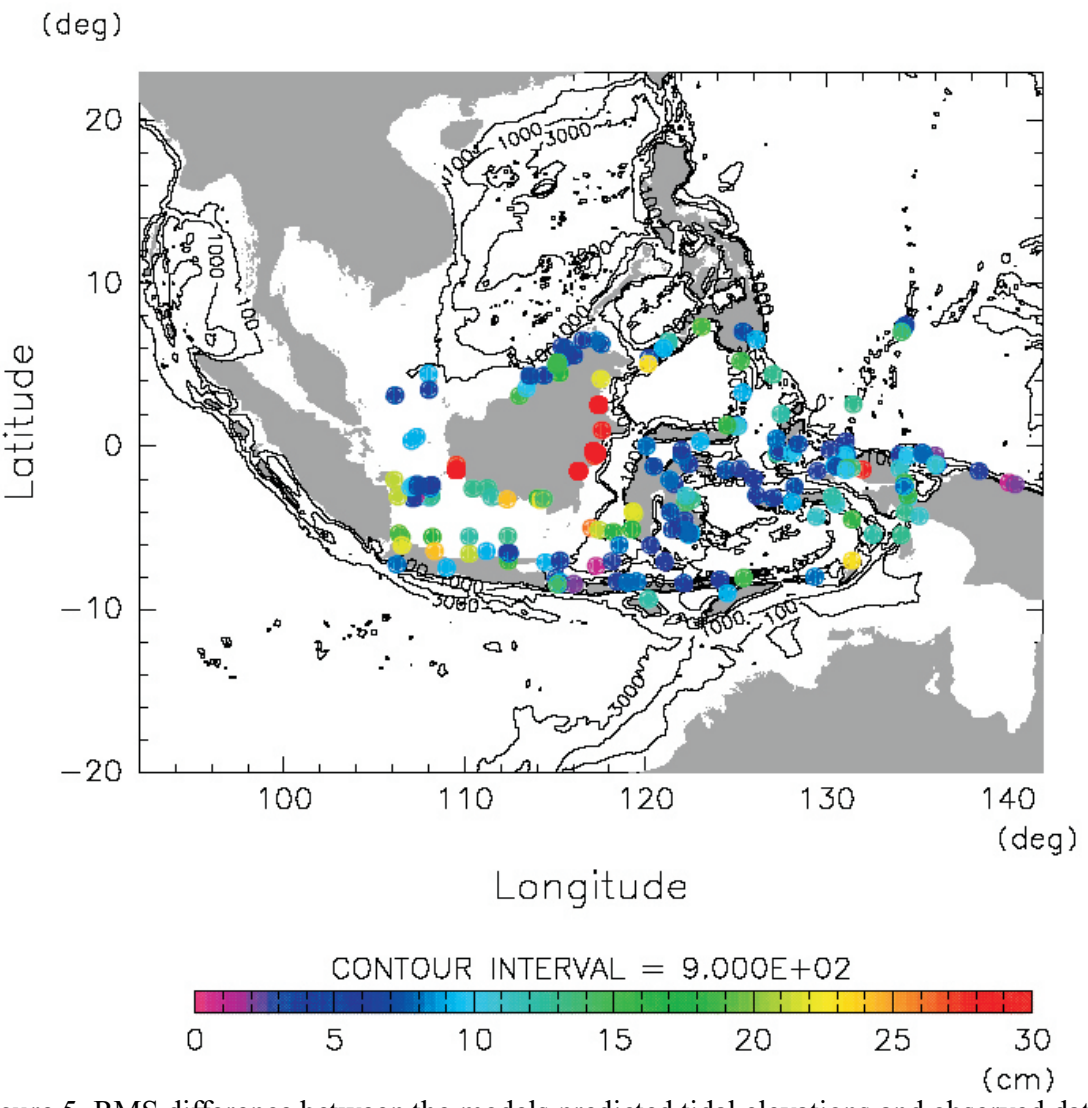

Figure 5. RMS difference between the models predicted tidal elevations and observed data.

\section{Parameterization for the Baroclinic Energy Conversion}

As mentioned before, large amount of incoming barotropic tidal energy is lost by the baroclinic energy conversion in the Indonesian Seas [Niwa and Hibiya, 2001; Egbert and Ray, 2001]. In order to reproduce accurate tidal elevations in the Indonesian Seas, the momentum equations (2) and (3) are modified to include the drag stress term associated with upward baroclinic energy flux in a manner similar to those of Jayne and St. Laurent [2001] and Tanaka et al. [2007].

Using a standard internal wave relationship, the upward energy flux over rough bottom topography can be expressed as

$$
F_{z}^{\prime} \cong \frac{\rho_{0}\left(N^{2}-\omega^{2}\right)^{1 / 2}\left(\omega^{2}-f^{2}\right)^{1 / 2}}{k \omega} w^{2}
$$

where $N$ is the buoyancy frequency; and $w$ is the vertical velocity associated with the upward propagating internal waves with horizontal wave number $k$ and frequency $\Omega$ $[$ Gill, 1982; St. Laurent and Garrett, 2002]. Strictly speaking, however, this expression is valid only for small scale topographic features and not for prominent topographic features found in the Indonesian Seas.

Since the area of concern is near the equator so that $f \cong 0$, and $N$ is much larger than the semidiurnal and/or diurnal tidal frequencies, the vertical energy flux (7) can be simplified to

$$
F_{z}^{\prime} \cong \frac{\rho_{0} N}{k} w^{2}
$$

Equation (8) provides rough estimates of baroclinic energy conversion when it is 
evaluated at the ocean bottom. $w$ at the ocean bottom is approximately given by

$$
w=u \frac{\partial h}{\partial x}+v \frac{\partial h}{\partial y}
$$

The drag stress term parameterizing the baroclinic energy conversion is then given by

$$
\begin{aligned}
& \tau_{x}=\frac{1}{k} N_{b} w^{2} \frac{u}{u^{2}+v^{2}} \\
& \tau_{y}=\frac{1}{k} N_{b} w^{2} \frac{v}{u^{2}+v^{2}}
\end{aligned}
$$

where $N_{b}$ is the buoyancy frequency at the ocean bottom which is calculated from a climatology of salinity [Levitus et al., 1994] and temperature [Levitus and Boyer, 1994]. Equations (10) and (11) are incorporated into the momentum equations (2) and (3).

Following Jayne and St. Laurent [2001] and Tanaka et al. [2007], horizontal wave number $k$ is regarded here as a tuning parameter to find the most accurate tidal elevation field in the Indonesian Seas. It is also expected for the parameter $k$ to compensate possible errors brought by several ambiguous assumptions in this parameterization such as somewhat crude incorporation of bottom boundary condition.

Figures 6,7 and 8 show the result of numerical experiment where the drag stress terms with the optimal value of $k=2 \pi /(100 \mathrm{~km})$ are incorporated into momentum equations. We find that the RMS difference averaged in the Indonesian Seas for numerical experiment with parameterization can be reduced down to $6.30 \mathrm{~cm}$, which is about half of the RMS difference for numerical experiment without parameterization $(11.18 \mathrm{~cm})$.

The results for the other three major tidal constituents $\left(\mathrm{S}_{2}, \mathrm{~K}_{1}, \mathrm{O}_{1}\right)$ are summarized in Table 1 . We can see that after incorporating the parameterization (10) and (11), the spatially averaged RMS difference is reduced by a factor of two for each tidal constituent.

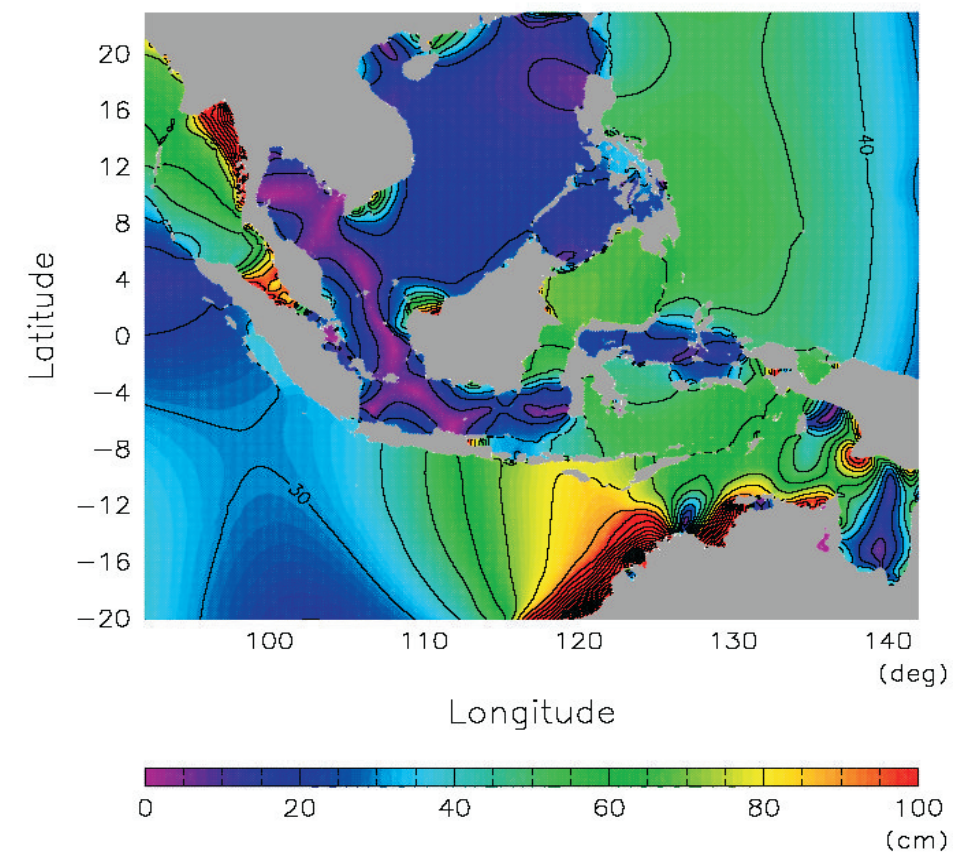

Figure 6. As in Figure 2, but for the result of numerical experiment including parameterization. 


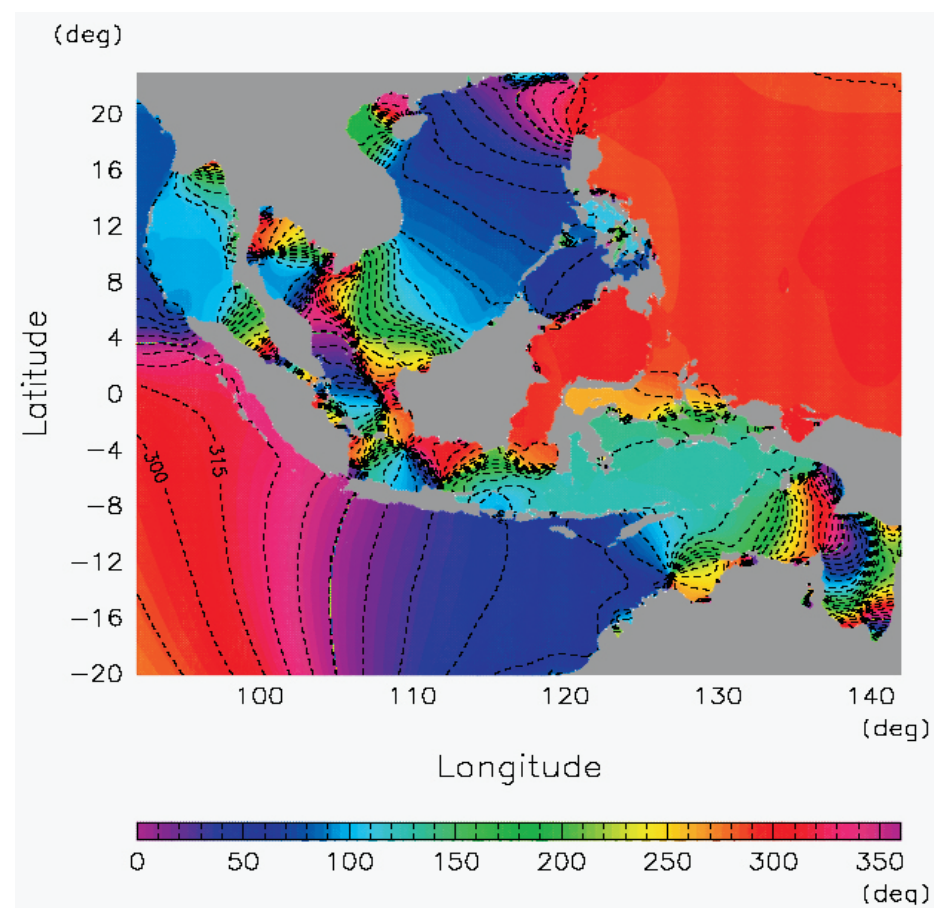

Figure 7. As in Figure 3, but for the result of numerical experiment including parameterization.
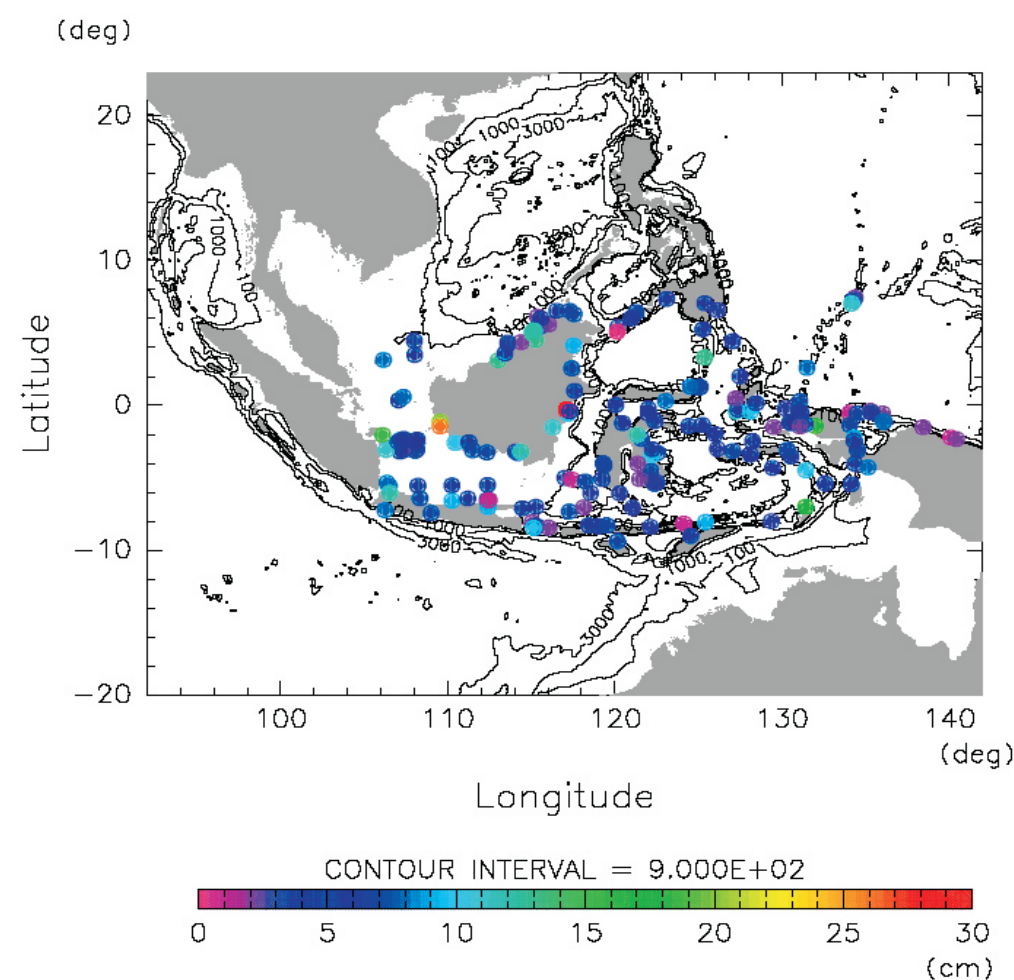

Figure 8. As in Figure 5, but for the result of numerical experiment including parameterization. 
Tabel 1. Averaged RMS difference between the model-predicted tidal elevations and observed data with and without parameterization, the value of the tuning parameter $k$ which gives the most accurate tidal elevations in the Indonesian Seas for the major four tidal constituents $\left(\mathrm{M}_{2}, \mathrm{~S}_{2}, \mathrm{~K}_{1}, \mathrm{O}_{1}\right)$

\begin{tabular}{lcccc}
\hline & $\mathrm{M}_{2}$ & $\mathrm{~S}_{2}$ & $\mathrm{~K}_{1}$ & $\mathrm{O}_{1}$ \\
\hline Without parameterization, cm & 11.18 & 7.62 & 12.06 & 10.44 \\
With parameterization, cm & 6.30 & 3.96 & 8.48 & 5.84 \\
Value of $2 \pi / k, \mathrm{~km}$ & 100 & 100 & 100 & 100 \\
\hline
\end{tabular}

5. Estimates of Energy Lost by the Barotropic Tides to Internal Waves

On the basis of the calculated result in the previous section, we can estimate the energy lost by the barotropic tides to internal waves in the Indonesian Seas. Equations (1) (3) can be combined into a single energy conservation equation given by

$$
\begin{aligned}
& \frac{\partial}{\partial \mathrm{t}}\left[\frac{1}{2} \rho_{0}\left(\mathrm{u}^{2}+\mathrm{v}^{2}\right) \mathrm{D} \quad \frac{1}{2} \rho_{0} \mathrm{~g} \eta^{2}\right]= \\
& -\nabla \cdot\left(\rho_{0} \mathrm{gD} \overrightarrow{\mathrm{u}} \eta\right)-\nabla\left[\frac{1}{2} \rho_{0}\left(\mathrm{u}^{2}+\mathrm{v}^{3} \overrightarrow{\mathrm{u} D}\right]+\rho_{0} \mathrm{gD} \overrightarrow{\mathrm{u}} . \nabla(\beta \zeta)\right. \\
& +\rho_{0} \mathrm{gD \vec {u }} \cdot \nabla \eta_{\mathrm{SAL}}-\rho_{0} \mathrm{C}_{\mathrm{d}}|\overrightarrow{\mathrm{u}}|^{3} \rho_{0} \frac{1}{\mathrm{k}} \mathrm{N}_{\mathrm{b}} \mathrm{w}^{2}-\mathrm{Dis}_{\mathrm{H}} .
\end{aligned}
$$

where $\mathrm{Dis}_{H}$ denotes the energy dissipation associated with the horizontal viscosity.

Figure 9 shows the spatial distribution of the sixth term on the right-hand side of equation (12) which represents the energy conversion from barotropic tides to internal waves. We can see that a large amount of energy is fed into internal waves in the Indonesian Seas especially over the ITF region with a series of large, deep, semi enclosed-basins connected via narrow straits. Three main regions of large energy conversion in the ITF routes can be distinguished on the map. The energy conversion for entrance routes of ITF is represented by energy distributions in the eastern (A) and western (B) areas. Exit routes are represented by southern area (C). Table 2 shows the estimates of each term in equation (12) integrated within the white rectangles in Figure 9. We can see that energy conversion from barotropic tides to internal waves reaches $\sim 51.9 \mathrm{GW}$ in the eastern area (Halmahera, Seram, Banda and Maluku Seas), $7.5 \mathrm{GW}$ in the western area (Makassar and Flores Seas), and $\sim 26.7 \mathrm{GW}$ in the southern area (Lombok Strait and Timor Passage). The spatial distribution of energy conversion in the entrance and exit routes of ITF is therefore highly heterogeneous. The results show A. B and C areas are "hot-spot" for internal waves generation with clear differences with other parts in the Indonesian Seas.

The results for the other three major tidal constituents $\left(\mathrm{S}_{2}, \mathrm{~K}_{1}, \mathrm{O}_{1}\right)$ are summarized in Table 3. The total energy conversion from barotropic tides to internal waves in the whole Indonesian Seas reaches $\sim 134.6 \mathrm{GW}$. 


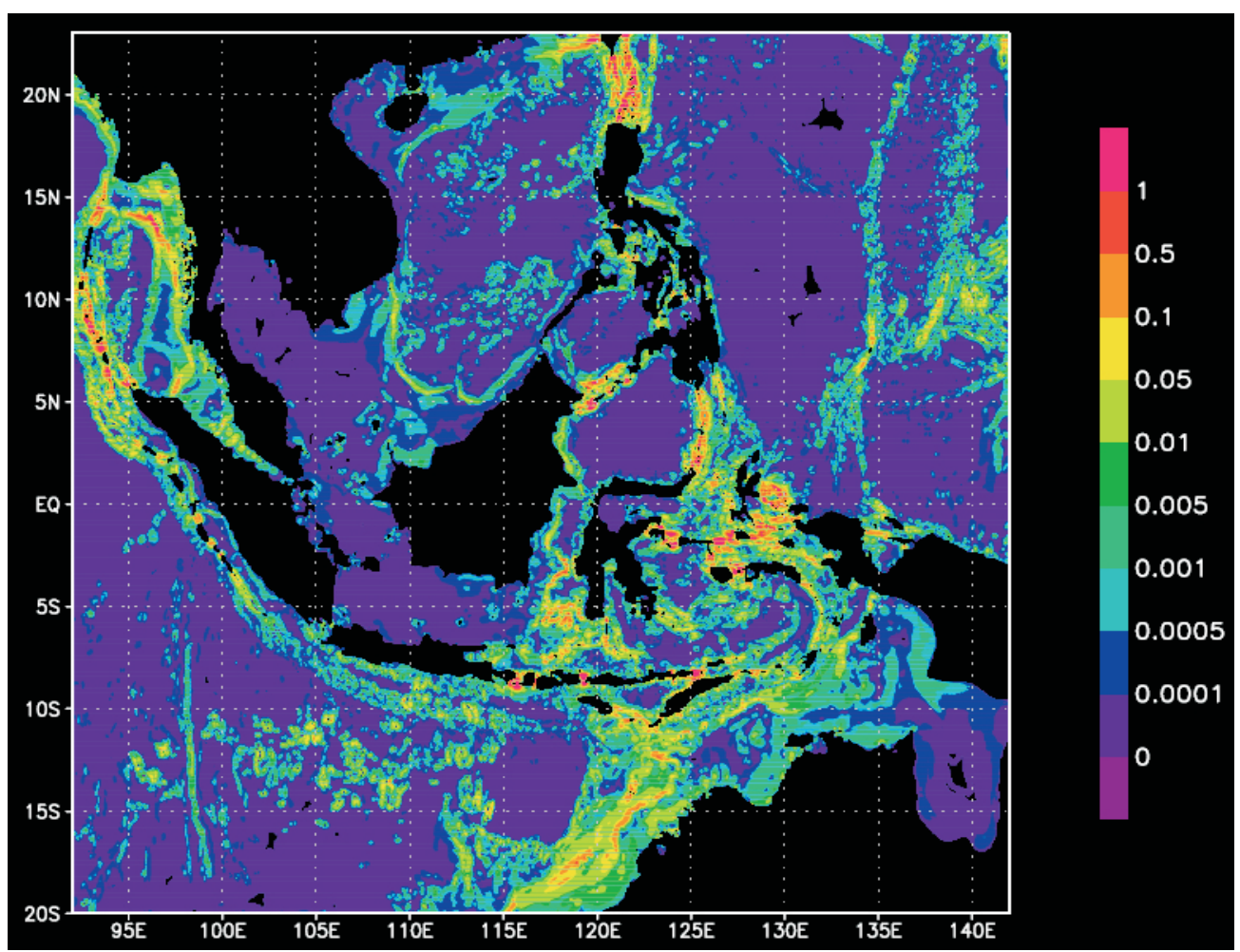

Figure 9. Model predicted distribution of the energy conversion rate from the barotropic tides to internal waves. The energy balance shown in Table 2 is examined within the white rectangles.

Tabel 2. Energy balance (GW) within the white rectangles in the Indonesian Seas ${ }^{\mathrm{a}}$

\begin{tabular}{|c|c|c|c|}
\hline Parameter & $\begin{array}{l}\text { Halmahera, Seram, } \\
\text { Maluku and Banda } \\
\text { Seas (A) }\end{array}$ & $\begin{array}{l}\text { Makasssar and } \\
\text { Flores Seas (B) }\end{array}$ & $\begin{array}{l}\text { Lombok Strait and } \\
\text { Timor Passages (C) }\end{array}$ \\
\hline Net energy flux into domain & -51.0 & -7.2 & -27.0 \\
\hline Work done by tidal forcing & 1.9 & -0.3 & 2.2 \\
\hline Work done by the solid earth & -5.1 & -0.8 & -3.6 \\
\hline $\begin{array}{l}\text { Energy dissipation rate due to } \\
\text { bottom friction }\end{array}$ & 1.9 & 0.7 & 2.4 \\
\hline $\begin{array}{l}\text { Energy dissipation rate due to } \\
\text { horizontal viscosity }\end{array}$ & 0.1 & 0.0 & 0.3 \\
\hline $\begin{array}{l}\text { Energy dissipation rate due } \\
\text { to internal wave generation }\end{array}$ & 51.9 & 7.5 & 26.7 \\
\hline
\end{tabular}

\footnotetext{
${ }^{\text {a }}$ See Figure 9.
} 
I Wayan Gede Astawa Karang, Fumihiko Nishio and Takahiro Osawa

Tabel 3. Estimates for the energy conversion from the barotropic tides to internal waves in the Indonesian Seas for the major four tidal constituents $\left(\mathrm{M}_{2}, \mathrm{~S}_{2}, \mathrm{~K}_{1}, \mathrm{O}_{1}\right)$

\begin{tabular}{ccccc}
\hline Energy conversion to internal wave (GW) & \multicolumn{2}{c}{ Semi diurnal } & \multicolumn{2}{c}{ Diurnal } \\
\cline { 2 - 4 } & $\mathrm{M} 2$ & $\mathrm{~S} 2$ & $\mathrm{~K} 1$ & $\mathrm{O} 1$ \\
\hline Halmahera, Maluku, Seram and Banda Seas & 51.9 & 10.3 & 17.4 & 7.8 \\
(A) & & & & \\
Makasar and Flores Seas (B) & 7.5 & 2.5 & 1.0 & 0.5 \\
Lombok Strait and Timor Passages (C) & 26.7 & 6.6 & 1.6 & 0.8 \\
Total & 86.1 & 19.4 & 20.0 & 9.1 \\
\hline
\end{tabular}

6. Estimates of Diapycnal Diffusivity in the Indonesian Seas

Turbulent dissipation rate $\varepsilon\left(\mathrm{W} \mathrm{kg}^{-1}\right)$ is related to the convergence of upward energy flux of internal waves emanating from the bottom topography. In the present study, the expression of $\varepsilon$ follows $S t$. Laurent et al. [2002] and Tanaka et al. [2007] such that

$$
\varepsilon=\frac{q}{p} E(x, y) F(z)
$$

where $E(\mathrm{x}, \mathrm{y})\left(\mathrm{W} \mathrm{m}^{-2}\right)$ is the baroclinic energy conversion, $q$ is the local dissipation efficiency, namely, the fraction of energy likely to dissipate locally by turbulent processes, and $F(\mathrm{z}) \quad\left(\mathrm{m}^{-1}\right)$ represents the depth dependence of dissipation rates satisfying

$$
\int_{-H}^{0} F(z) d z=1
$$

Following St. Laurent et al. [2002] and Tanaka et al. [2007], we assume

$$
F(z) \frac{\exp [-(H+z) / \zeta]}{\zeta[1-\exp (-H / \zeta]}
$$

with $\quad \& 500 \mathrm{~m}$. Although $q=0.3$ is suggested as an upper bound "local dissipation efficiency" for the semidiurnal internal tides [St. Laurent and Garrett, 2002; Klymak et al., 2006; Legg and Huijts, 2006], there is no definite general information on the value of $q$. Bearing in mind that there must be large uncertainty of the value of $q$, we employ here a crude assumption of $q=0.3$ for both the semidiurnal and diurnal internal tides.

The diapycnal diffusivity is estimated following Osborn [1980], namely,

$K \rho=\frac{\gamma \varepsilon}{N^{2}} \quad \frac{\gamma q E(x, y) F(z)}{\rho N^{2}}$

where $\gamma$ is the mixing efficiency assumed to be 0.2 [Osborn, 1980]. Figure 10 shows the distribution of diapycnal diffusivity $K_{\rho}$ vertically averaged throughout the water column. As in Figure 9, three main regions of high diapycnal diffusivity value can be distinguished. We can see that the distribution of $K_{\rho}$ is close to the distribution of energy conversion on the Figure 9.

Although significant diapycnal mixing with $K \rho>100 \times 10^{-4} \mathrm{~m}^{2} \mathrm{~s}^{-1}$ can be found in the Indonesian Seas, such "mixing hot spots" are much limited. The value of $K \rho$ averaged within the eastern area (Halmahera, Seram, Banda and Maluku Seas), the western area (Makassar and Flores Seas), and the southern area (Lombok Strait and Timor Passage) are estimated to be $\sim 23 \times 10^{-4} \mathrm{~m}^{2} \mathrm{~s}^{-1}, \sim 5 \times 10^{-4}$ $\mathrm{m}^{2} \mathrm{~s}^{-1}$, and $\sim 10 \times 10^{-4} \mathrm{~m}^{2} \mathrm{~s}^{-1}$, respectively. 


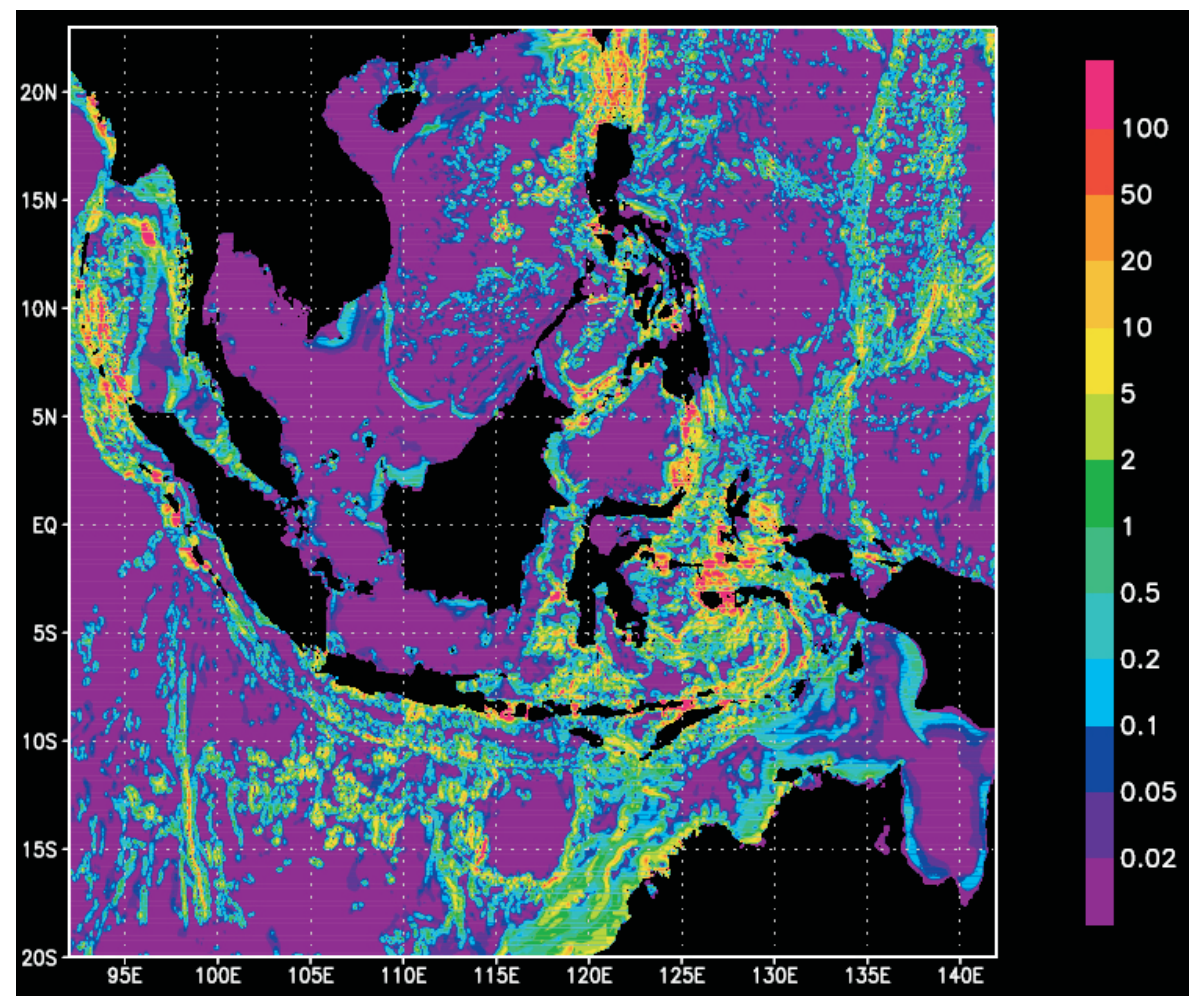

Figure 10. Distribution of diapycnal diffusivity vertically averaged throughout the water column.

\section{Summary and Discussion}

In the present study, quantitative estimates of diapycnal diffusivity in the Indonesian Seas have been carried out. For this purpose, we have paid attention to the result of numerical experiment that, to reproduce realistic tidal elevation field in the Indonesian Seas and surrounding regions, the energy lost by the incoming barotropic tides to internal waves within the Indonesian Seas should be taken into account.

We have parameterized this baroclinic energy conversion in terms of drag stress terms which are incorporated into the momentum equations. It has been shown that the model predicted tidal elevations in the Indonesian Seas best fit the observed data when we take into account the baroclinic energy conversion in the Indonesian Seas $\sim 86.1 \mathrm{GW}$ for the $\mathrm{M}_{2}$ tidal constituent and $\sim 134.6 \mathrm{GW}$ for the major four tidal constituents $\left(\mathrm{M}_{2}, \mathrm{~S}_{2}, \mathrm{~K}_{1}, \mathrm{O}_{1}\right)$.

On the basis of this energy conversion, we have estimated diapycnal diffusivity. It has been shown that the value of $K_{\rho}$ vary from a few $10^{-4} \mathrm{~m}^{2} \mathrm{~s}^{-1}$ to a hundreds of $10^{-4}$ $\mathrm{m}^{2} \mathrm{~s}^{-1}$. The averaged value of $K \rho$ becomes $\sim 23 \times 10^{-4} \mathrm{~m}^{2} \mathrm{~s}^{-1}$ for the eastern area (Halmahera, Seram, Banda and Maluku Seas), $\sim 5 \times 10^{-4} \mathrm{~m}^{2} \mathrm{~s}^{-1}$ for the western area (Makasar and Flores Seas), and $\sim 10 \times 10^{-4}$ $\mathrm{m}^{2} \mathrm{~s}^{-1}$ for the southern area (Lombok Strait and Timor Passage), respectively.

There are some limitations with the numerical approach in the present study. Most serious one may be found in the oversimplified parameterization for the baroclinic energy conversion. For more accurate estimates of diapycnal diffusivity in the Indonesian Seas, a sophisticated parameterization better suited for prominent topographic features is 
necessary. We also need more accurate information about the local dissipation efficiency $q$. In order to reproduce more realistic tidal elevation field in the Indonesian Seas, we might also need more accurate bathymetry data and high resolution numerical experiment [Koropitan and Ikeda, 2008].

Not only the averaged value but also the spatial distributions of $K \rho$ revealed in the present study are very different from those assumed in the previous ocean general circulation models [Schiller et al., 1998]. Diapycnal mixing in the Indonesian Seas is known to have great impacts on large scale circulation and water mass properties not only in the Indonesian Seas but also in the Indian Ocean. We believe that the spatial distribution of $K \rho$ revealed here, therefore, must be taken into account in the future numerical models in order to better understand the global ocean circulation.

\section{Acknowledgement}

The authors express their gratitude to K. Matsumoto and T. Hibiya for kindly providing Tidal Harmonic data. The author also likes to thank BPKLN under Ministry of National Education for funding scholarship to the author. This work is a collaborative work between Chiba University, University of Tokyo and Udayana University.

\section{References}

Egbert, G. D., and R. D. Ray (2001), Estimates of $\mathrm{M}_{2}$ tidal energy dissipation from Topex/Poseidon altimeter data, J. Geophys. Res., 106, 22,475-22,502.

Ffield, A., and A. L. Gordon (1992), Vertical mixing in the Indonesian thermocline, J. Phys. Oceanogr., 22, 184-195.

Ffield, A., and A. L. Gordon (1996), Tidal mixing signatures in the Indonesian
Seas, J. Phys. Oceanogr., 26, 1,9241,937 .

Gill, A. E. (1982), Atmosphere-Ocean Dynamics, 662 pp., Academic Press, San Diego, Calif.

Gordon, A. (1986), Interocean exchange of thermohaline water, J. Geophys. Res., 91, 5037-5046.

Gordon, A. L., A. Ffield and A. G. Ilahude (1994), Thermocline of the Flores and Banda Seas, J. Geophys. Res., 99, 18,235-18,242.

Hatayama, T., T. Awaji, and K. Akitomo (1996), Tidal currents in the Indonesian Seas and their effect on transfort and mixing, J. Geophys. Res., 101, 12,353-12,373.

Hatayama, T. (2004), Transformation of the Indonesian Throughflow water by vertical mixing and its relation to tidally generated internal waves, $J$. Oceanogr., 60, 569-585.

Hirst, A. C., and J. S. Godfrey (1993), The role of Indonesian Throughflow in a global ocean GCM, J. Phys. Oceanogr., 23, 1057-1086.

Jayne, S. R., and L. C. St. Laurent (2001), Parameterizing tidal dissipation over rough topography, Geophys. Res. Lett., 28, 811-814.

Kantha, L. H. (1995), Barotropic tides in the global oceans from a nonlinear tidal model assimilating altimetric tides: 1. Model description and results, J. Geophys. Res., 100, 25,283 $-25,308$.

Klymak, J. M., J. N. Moum, J. D. Nash, E. Kunze, J. B. Girton, G. S. Carter, C. M. Lee, T. B. Sanford, and M. C. Gregg (2006), An estimate of tidal energy lost to turbulence at the Hawaiian Ridge, J. Phys. Oceanogr., 36, 1148-1164.

Koropitan, A. F, and M. Ikeda (2008), Three-dimensional modeling of tidal circulation and mixing over the Java Sea, J. Oceanogr. , 64, 61-80. 
Larrouy, A. K., G. Madec, P. B. Aubertot, T. Gerkema, L. Bessieres, and R. Molcard (2007), On the transformation of Pacific Water into Indonesian Throughflow Water by internal tidal mixing, Geophys. Res. Lett., 34, L04604, doi: 10.1029/2006GL028045.

Legg, S., and K. M. H. Huijts (2006), Preliminary simulations of internal waves and mixing generated by finite amplitude tidal flow over isolated topography, Deep Sea Res., Part II, 53, 140-156.

Levitus, S., and T. P. Boyer (1994), World Ocean Atlas 1994, vol. 4, Temperature, NOAA Atlas NESDIS, vol. 4, NOAA, Silver Spring, Md.

Levitus, S., R. Burgett, and T. P. Boyer (1994), World Ocean Atlas 1994, vol. 3, Salinity, NOAA Atlas NESDIS, vol. 4, NOAA, Silver Spring, Md.

Matsumoto, K., T. Takanezawa, and M. Ooe (2000), Ocean tide models developed by assimilating TOPEX/POSEIDON altimeter data into hydro dynamical model: A global model and regional model around Japan, J. Oceanogr., 56, $567-581$.

Miyama, T., T. Awaji, K. Akitomo, and N. Imasato (1995), Study of seasonal transport variations in the Indonesian Seas, J. Geophys. Res., 100, 20,51720,541 .

Niwa, Y., and T. Hibiya (2001), Numerical study of the spatial distribution of the $\mathrm{M}_{2}$ internal tide in the Pacific Ocean, J. Geophys. Res., 106, 22,441-22,449.

Osborn, T. R. (1980), Estimates of the local rate of vertical diffusion from dissipation measurements, J. Phys. Oceanogr., 10, 83-89.
Polzin, K. L., J. M. Toole, J. R. Ledwell, and R. W. Schmitt (1997), Spatial variability of turbulent mixing in the abyssal ocean, Science., 276, 93-96.

Ray, R. D., G. D. Egbert and S. Y. Erofeeva (2005), A brief overview of tides in the Indonesian Seas, Oceanography., 18, 74-79.

Schiller, A., J. S. Godfrey, P. C. McIntosh, and G. Meyers, S. E. Wijffels (1998), Seasonal near-surface dynamics and thermodynamics of the Indian Ocean and Indonesian Throughflow in a global ocean general circulation model, J. Phys. Oceanogr., 28, 22882312 .

Simmons, H. L., R. W. Hallberg, and B. K. Arbic (2004), Internal wave generation in a global baroclinic tide model, Deep Sea. Res., 51, 30433068

Smagorinsky, J. S. (1963), General circulations experiments with the primitive equations, I, The basic experiment, Mon. Weather Rev., 91, 99-164.

St. Laurent, L. C., and C. Garrett (2002), The role of internal tides in mixing deep ocean, J. Phys. Oceanogr., 32, 2882-2899.

St. Laurent, L. C., H. L. Simmons, and S. R. Jayne (2002), Estimating tidally driven mixing in the deep ocean, Geophys. Res. Lett., 29, 2106, doi:10.1029/2002GL015633.

Tanaka, Y., T. Hibiya, and Y. Niwa (2007), Estimates of tidal energy dissipation and diapycnal diffusivity in the Kuril Straits using TOPEX/POSEIDON altimeter data, $J$. Geophys. Res., 112, C10021, doi: 10.1029/2007JC004172. 
Appendix: Observed data obtained from international tides gauges record in the surrounding Indonesian Seas

\begin{tabular}{|c|c|c|c|c|c|c|c|c|c|c|c|}
\hline \multirow[t]{2}{*}{ No } & \multirow{2}{*}{$\begin{array}{l}\text { Longitude } \\
\mathrm{E}\end{array}$} & \multirow{2}{*}{$\frac{\text { Latitude }}{\mathrm{N}(+) / \mathrm{S}(-}$} & \multirow{2}{*}{ Station } & \multicolumn{4}{|c|}{ Amplitude (m) } & \multicolumn{4}{|c|}{ Phase (deg) } \\
\hline & & & & M2 & $\mathrm{S} 2$ & $\mathrm{~K} 1$ & $\mathrm{O} 1$ & M2 & $\mathrm{S} 2$ & $\mathrm{~K} 1$ & $\mathrm{O} 1$ \\
\hline 1 & 113.59 & 4.23 & Miri & 0.16 & 0.08 & 0.36 & 0.31 & 341.9 & 22 & 323.3 & 270.6 \\
\hline 2 & 121 & 6.04 & Jolo & 0.17 & 0.11 & 0.26 & 0.25 & 226.6 & 272.3 & 315.1 & 274.9 \\
\hline 3 & 115.04 & 5.02 & Muara Harbour & 0.31 & 0.15 & 0.4 & 0.36 & 346 & 25 & 329 & 271 \\
\hline 4 & 115.24 & 4.51 & Pasar Lawas & 0.31 & 0.14 & 0.47 & 0.41 & 339 & 29 & 313 & 264 \\
\hline 5 & 114.39 & 4.37 & Seria & 0.21 & 0.08 & 0.35 & 0.31 & 300 & 1 & 313 & 265 \\
\hline 6 & 125.38 & 7.05 & Davao & 0.59 & 0.3 & 0.15 & 0.02 & 155.4 & 197.1 & 237.5 & 207.6 \\
\hline 7 & 131.49 & 2.59 & Heren Syo & 0.49 & 0.23 & 0.19 & 0.16 & 203.2 & 229.4 & 212.6 & 194.7 \\
\hline 8 & 121.58 & -2.32 & Boengkoe & 0.44 & 0.18 & 0.27 & 0.18 & 359.9 & 67.1 & 293.4 & 258.6 \\
\hline 9 & 122.55 & -3.28 & Poeloe Kokoila & 0.54 & 0.17 & 0.28 & 0.19 & 20 & 84.2 & 304.4 & 291.6 \\
\hline 10 & 122.51 & -5.31 & Wadjo B & 0.49 & 0.15 & 0.31 & 0.17 & 9.2 & 89.3 & 304.5 & 276.7 \\
\hline 11 & 122.37 & -5.28 & Boeton & 0.53 & 0.16 & 0.31 & 0.2 & 6.6 & 70.8 & 310.7 & 280.9 \\
\hline 12 & 122.38 & -5.42 & Bola (Boeton) & 0.5 & 0.14 & 0.27 & 0.21 & 7.6 & 55.7 & 305.7 & 281.9 \\
\hline 13 & 107.06 & 0.35 & Tebon Islet & 0.05 & 0.03 & 0.28 & 0.27 & 175.7 & 127.8 & 114.2 & 30.5 \\
\hline 14 & 107.34 & 0.59 & Tambelan B & 0.09 & 0.04 & 0.2 & 0.23 & 101.8 & 149.9 & 92.7 & 24 \\
\hline 15 & 122.16 & -4.53 & Poloe Galia & 0.68 & 0.23 & 0.35 & 0.2 & 11.3 & 74.5 & 303.1 & 280.3 \\
\hline 16 & 122.18 & -5.13 & Tampona Who & 0.57 & 0.17 & 0.33 & 0.21 & 8.3 & 63.4 & 303 & 279.2 \\
\hline 17 & 121.48 & -5.1 & Poeloe Baleara & 0.56 & 0.18 & 0.37 & 0.19 & 358.3 & 57.4 & 292.5 & 275.7 \\
\hline 18 & 120.28 & -6.07 & Benteng & 0.39 & 0.1 & 0.32 & 0.21 & 354.9 & 66.1 & 299.9 & 272.1 \\
\hline 19 & 114.47 & -7.1 & Poeloe Telangoe & 0.25 & 0.15 & 0.4 & 0.22 & 320.8 & 324.4 & 300 & 264.8 \\
\hline 20 & 115.27 & -7 & Saoebi, Kangean & 0.26 & 0.14 & 0.27 & 0.17 & 317.5 & 342.8 & 298.4 & 270.1 \\
\hline 21 & 115.05 & -8.06 & Buleleng, Bali & 0.29 & 0.15 & 0.31 & 0.21 & 321.2 & 342.8 & 308.7 & 256.5 \\
\hline 22 & 115.3 & -8.32 & Teluk Padang & 0.34 & 0.17 & 0.32 & 0.17 & 301.4 & 337 & 296.3 & 262.1 \\
\hline 23 & 115.3 & -8.41 & Sanur, Bali & 0.57 & 0.14 & 0.38 & 0.2 & 276.4 & 333 & 321.3 & 256.1 \\
\hline 24 & 121.06 & -7.07 & Kg. Bone Rate & 0.45 & 0.11 & 0.31 & 0.19 & 0.7 & 56.8 & 294.2 & 281.4 \\
\hline 25 & 109 & -7.44 & Cilacap & 0.5 & 0.25 & 0.19 & 0.12 & 248.4 & 318 & 282.8 & 263.6 \\
\hline 26 & 106.24 & -7.24 & Genteng B & 0.37 & 0.19 & 0.12 & 0.07 & 234.6 & 307.2 & 256.4 & 240.2 \\
\hline 27 & 106.36 & -5.35 & Duizend E. & 0.01 & 0.05 & 0.28 & 0.07 & 270.2 & 22.8 & 171.2 & 136 \\
\hline 28 & 112.38 & -5.5 & Sangkapura B & 0.04 & 0.05 & 0.43 & 0.25 & 64.1 & 15.7 & 326.2 & 291.9 \\
\hline 29 & 112.34 & -6.54 & Ujung Pangka & 0.03 & 0.06 & 0.51 & 0.24 & 125.2 & 11.9 & 326.2 & 271 \\
\hline 30 & 112.48 & -6.54 & Tanjung Modeng & 0.02 & 0.06 & 0.52 & 0.24 & 95.8 & 8.4 & 326 & 253.8 \\
\hline 31 & 112.44 & -6.56 & Karang Jamuang & 0.04 & 0.08 & 0.54 & 0.26 & 16 & 356 & 317 & 259 \\
\hline 32 & 112.41 & $-7-.02$ & Sembilangan & 0.18 & 0.16 & 0.46 & 0.25 & 348 & 3.6 & 319.1 & 268.9 \\
\hline 33 & 116.03 & -8.43 & Labuan Tring B & 0.27 & 0.16 & 0.35 & 0.23 & 308.3 & 316.9 & 283.8 & 264.5 \\
\hline 34 & 117.27 & -7.32 & Poeloe Sailoes & 0.3 & 0.11 & 0.33 & 0.26 & 6 & 67.1 & 294.9 & 274.1 \\
\hline 35 & 118.13 & -7.04 & Poeloe Sapoeka & 0.34 & 0.1 & 0.35 & 0.2 & 359.4 & 343.6 & 301.1 & 282.3 \\
\hline 36 & 118.43 & -8.27 & Bima & 0.35 & 0.1 & 0.3 & 0.1 & 3.4 & 54.6 & 303.6 & 255.8 \\
\hline 37 & 119.02 & -8.34 & Safe B. Sumbawa & 0.49 & 0.18 & 0.2 & 0.2 & 347.8 & 37.9 & 288.3 & 269.5 \\
\hline 38 & 119.53 & -8.29 & Labuan Badjo & 0.46 & 0.16 & 0.27 & 0.17 & 343.1 & 39.2 & 288.4 & 284.7 \\
\hline
\end{tabular}


Etimation of Tidal Energy

\begin{tabular}{|c|c|c|c|c|c|c|c|c|c|c|c|}
\hline \multirow[t]{2}{*}{ No } & \multirow{2}{*}{$\begin{array}{l}\text { Longitude } \\
\mathrm{E}\end{array}$} & \multirow{2}{*}{$\frac{\text { Latitude }}{\mathrm{N}(+) / \mathrm{S}(-)}$} & \multirow[t]{2}{*}{ Station } & \multicolumn{4}{|c|}{ Amplitude (m) } & \multicolumn{4}{|c|}{ Phase (deg) } \\
\hline & & & & M2 & $\mathrm{S} 2$ & K1 & $\mathrm{O} 1$ & M2 & S2 & K1 & $\mathrm{O} 1$ \\
\hline 39 & 122.13 & -8.39 & Maoemere & 0.53 & 0.16 & 0.3 & 0.24 & 2.4 & 61.6 & 301.1 & 275.3 \\
\hline 40 & 120.15 & -9.38 & Nangamessi B. & 0.83 & 0.41 & 0.26 & 0.16 & 298.4 & 349.5 & 287.1 & 275.3 \\
\hline 41 & 131.06 & 0.3 & Ajoe, New Guine & 0.55 & 0.19 & 0.1 & 0.14 & 181.7 & 235.8 & 214.3 & 197.4 \\
\hline 42 & 134.32 & -2.22 & Jende, New G. & 0.57 & 0.23 & 0.21 & 0.14 & 209.8 & 223.9 & 201.8 & 189 \\
\hline 43 & 134.53 & -3.12 & Kwatisore Bay & 0.61 & 0.21 & 0.2 & 0.13 & 199.1 & 237.2 & 214.5 & 188.6 \\
\hline 44 & 134.5 & -3 & Moor Islets & 0.54 & 0.24 & 0.21 & 0.14 & 209.2 & 240.3 & 213.5 & 184.7 \\
\hline 45 & 124.13 & -8.16 & Kabir, Pantar I. & 0.53 & 0.21 & 0.25 & 0.24 & 357.4 & 64.6 & 298.1 & 264.3 \\
\hline 46 & 124.53 & -9.01 & Atapoepoe & 0.56 & 0.31 & 0.21 & 0.15 & 318.1 & 14.2 & 298.4 & 261.7 \\
\hline 47 & 129.5 & -1.5 & Waigama & 0.18 & 0.19 & 0.17 & 0.1 & 98.2 & 181.3 & 299.5 & 269.7 \\
\hline 48 & 127.26 & -0.41 & Laboeha & 0.09 & 0.1 & 0.21 & 0.08 & 54.5 & 174.1 & 273.4 & 215.1 \\
\hline 49 & 127.36 & -0.3 & Sabatang & 0.22 & 0.17 & 0.19 & 0.15 & 146.2 & 198.8 & 268.2 & 240.9 \\
\hline 50 & 128.12 & -0.42 & Cane B. & 0.16 & 0.14 & 0.2 & 0.1 & 100 & 161.6 & 277.6 & 270.3 \\
\hline 51 & 127.22 & 0.47 & Ternate Island & 0.27 & 0.22 & 0.14 & 0.1 & 160.6 & 197.3 & 261.5 & 240.1 \\
\hline 52 & 127.48 & 2 & Asimiro & 0.4 & 0.18 & 0.16 & 0.12 & 175.8 & 223.4 & 235 & 206.7 \\
\hline 53 & 128.45 & 0.15 & Patani & 0.14 & 0.15 & 0.14 & 0.1 & 133.9 & 187.5 & 265.1 & 206.8 \\
\hline 54 & 131.06 & -1 & Samate & 0.42 & 0.18 & 0.23 & 0.12 & 190.7 & 233.8 & 208.3 & 195.4 \\
\hline 55 & 131.13 & -0.5 & Sorong & 0.41 & 0.18 & 0.23 & 0.13 & 194.4 & 209.6 & 226.2 & 171.3 \\
\hline 56 & 131.01 & -0.54 & Poeloe Jef Doif & 0.44 & 0.17 & 0.16 & 0.1 & 199.8 & 241 & 210.4 & 206.5 \\
\hline 57 & 130.2 & -0.21 & Moetoes Besar & 0.28 & 0.19 & 0.17 & 0.1 & 170.2 & 217.3 & 263 & 253.2 \\
\hline 58 & 127.06 & -3.16 & Kajeli Bay & 0.34 & 0.12 & 0.2 & 0.11 & 15.2 & 111.8 & 306.7 & 270.4 \\
\hline 59 & 126.13 & -3 & Bara Bay & 0.4 & 0.13 & 0.33 & 0.17 & 20.9 & 100.6 & 309.6 & 286.3 \\
\hline 60 & 126 & -2 & Sanana & 0.28 & 0.12 & 0.31 & 0.21 & 49.4 & 145 & 298.8 & 269.5 \\
\hline 61 & 124.42 & -1.42 & Gela & 0.13 & 0.19 & 0.17 & 0.09 & 123 & 218.6 & 272.1 & 231.8 \\
\hline 62 & 125.24 & -1.36 & Dofa & 0.18 & 0.18 & 0.24 & 0.16 & 116.6 & 197.2 & 272.4 & 233.1 \\
\hline 63 & 125.12 & 1.27 & Kg. Aer Tembaga & 0.36 & 0.26 & 0.26 & 0.13 & 146 & 191 & 258 & 226 \\
\hline 64 & 134.3 & -2.44 & Wassior & 0.61 & 0.24 & 0.22 & 0.16 & 209 & 256 & 223 & 196 \\
\hline 65 & 121.28 & 6.44 & Dassalan Island & 0.2 & 0.12 & 0.27 & 0.22 & 242.9 & 280.1 & 306.9 & 265.1 \\
\hline 66 & 120.17 & 5.39 & North Lahatlahat & 0.13 & 0.09 & 0.23 & 0.22 & 229.3 & 267.4 & 303 & 266.3 \\
\hline 67 & 123.1 & 7.35 & Margosatubig & 0.62 & 0.37 & 0.14 & 0.12 & 162.5 & 206.7 & 258.2 & 238.4 \\
\hline 68 & 125.26 & 5.25 & Lajan Point & 0.57 & 0.31 & 0.18 & 0.12 & 160 & 200.1 & 249. & 218.1 \\
\hline 69 & 126.13 & 6.57 & Pujada Bay & 0.55 & 0.24 & 0.17 & 0.13 & 158.4 & 191.6 & 207.1 & 182.3 \\
\hline 70 & 107.33 & -3.12 & Selioe Island & 0.09 & 0.06 & 0.51 & 0.34 & 29 & 21 & 142 & 92 \\
\hline 71 & 108.05 & -3.14 & Tg. Batoe Hitam & 0.09 & 0.01 & 0.38 & 0.23 & 346 & 76 & 137 & 68 \\
\hline 72 & 108.16 & -3.04 & Ajam Besar & 0.08 & 0.01 & 0.4 & 0.24 & 351 & 76 & 136 & 87 \\
\hline 73 & 113.02 & 3.11 & Kwala Bintulu & 0.16 & 0.06 & 0.47 & 0.32 & 44 & 32 & 320 & 271 \\
\hline 74 & 117.19 & -0.59 & Kutei River & 0.51 & 0.4 & 0.21 & 0.15 & 133 & 193 & 271 & 248 \\
\hline 75 & 115.36 & 6.12 & Palau Mangalum & 0.24 & 0.1 & 0.34 & 0.31 & 320 & 358 & 312 & 275 \\
\hline 76 & 119.36 & -4.13 & Tg. Lasonraai & 0.13 & 0.22 & 0.25 & 0.2 & 128 & 220 & 297 & 267 \\
\hline 77 & 106.15 & 3.14 & Salat Peninting & 0.19 & 0.06 & 0.39 & 0.29 & 240 & 285 & 359 & 315 \\
\hline 78 & 117.55 & 6.3 & Lankayan Island & 0.33 & 0.18 & 0.33 & 0.3 & 310 & 347 & 322 & 278 \\
\hline
\end{tabular}


I Wayan Gede Astawa Karang, Fumihiko Nishio and Takahiro Osawa

\begin{tabular}{|c|c|c|c|c|c|c|c|c|c|c|c|}
\hline \multirow[t]{2}{*}{ No } & \multirow{2}{*}{$\begin{array}{l}\text { Longitude } \\
\text { E }\end{array}$} & \multirow{2}{*}{$\begin{array}{r}\text { Latitude } \\
\mathrm{N}(+) / \mathrm{S}(-)\end{array}$} & \multirow[t]{2}{*}{ Station } & \multicolumn{4}{|c|}{ Amplitude (m) } & \multicolumn{4}{|c|}{ Phase (deg) } \\
\hline & & & & M2 & $\mathrm{S} 2$ & $\mathrm{~K} 1$ & $\mathrm{O} 1$ & M2 & $\mathrm{S} 2$ & K1 & $\mathrm{O} 1$ \\
\hline 79 & 117.29 & 6.53 & Tigabu Island & 0.33 & 0.18 & 0.37 & 0.31 & 312 & 353 & 320 & 280 \\
\hline 80 & 115.54 & 5.45 & Kuala Papar & 0.21 & 0.1 & 0.35 & 0.3 & 308 & 352 & 312 & 261 \\
\hline 81 & 115.4 & 5.42 & Pulau Tega & 0.26 & 0.11 & 0.36 & 0.31 & 317 & 0 & 315 & 254 \\
\hline 82 & 107.15 & -2.39 & Akbar Droogte & 0.05 & 0.06 & 0.53 & 0.48 & 129 & 79 & 159 & 107 \\
\hline 83 & 107.3 & -3 & Poeloe Roe & 0.05 & 0.06 & 0.57 & 0.32 & 61 & 79 & 146 & 90 \\
\hline 84 & 125.37 & 3.31 & Menaloe, Sangi I. & 0.54 & 0.37 & 0.22 & 0.12 & 149.6 & 199.8 & 247.7 & 226.9 \\
\hline 85 & 134.36 & -4.04 & Poeloe Lakahita & 0.62 & 0.18 & 0.28 & 0.19 & 42 & 114 & 342 & 329 \\
\hline 86 & 136.12 & -1.11 & Bosnik, Biak & 0.45 & 0.17 & 0.25 & 0.15 & 193.5 & 230.6 & 216.2 & 179.3 \\
\hline 87 & 136.02 & -0.55 & Korim, Biak & 0.42 & 0.12 & 0.19 & 0.15 & 188.8 & 228.9 & 208.3 & 185.5 \\
\hline 88 & 135.3 & -0.38 & Mios Woendi & 0.44 & 0.19 & 0.25 & 0.14 & 189.9 & 220 & 224.9 & 188 \\
\hline 89 & 140.1 & -2.21 & Demta Bay & 0.32 & 0.08 & 0.25 & 0.15 & 192.5 & 232.7 & 207.2 & 181.3 \\
\hline 90 & 106.5 & -5.57 & Edam & 0.05 & 0.07 & 0.27 & 0.08 & 312.2 & 334.3 & 154.5 & 133.7 \\
\hline 91 & 108.21 & -5.55 & Boompjes Island & 0.11 & 0.06 & 0.14 & 0.07 & 339.2 & 241.3 & 114 & 121.2 \\
\hline 92 & 108.34 & -6.42 & Cheribon & 0.16 & 0.1 & 0.14 & 0.05 & 332.7 & 206.9 & 63.8 & 169 \\
\hline 93 & 110.25 & -5.53 & Karimoen Djawa & 0.02 & 0.05 & 0.23 & 0.04 & 257 & 3.2 & 6.9 & 263.1 \\
\hline 94 & 110.25 & -6.58 & Semarang & 0.1 & 0.08 & 0.22 & 0.08 & 286 & 187.2 & 8.9 & 246.1 \\
\hline 95 & 111.2 & -6.43 & Rembang & 0.04 & 0.02 & 0.41 & 0.15 & 7.2 & 337.3 & 352 & 256.2 \\
\hline 96 & 106.11 & -2.05 & Pangkal Pinang & 0.06 & 0.02 & 0.72 & 0.54 & 172.5 & 327.6 & 142.1 & 74.4 \\
\hline 97 & 107.13 & -3.19 & Ondiepwater & 0.08 & 0.07 & 0.53 & 0.28 & 83.4 & 67.6 & 159.1 & 103.3 \\
\hline 98 & 107.37 & -2.32 & Poeloe Langkoeas & 0.02 & 0.03 & 0.64 & 0.38 & 253.6 & 40.8 & 153.7 & 89.9 \\
\hline 99 & 108.18 & -2.36 & Manggar & 0.02 & 0.06 & 0.41 & 0.27 & 18.3 & 351.4 & 152 & 108.2 \\
\hline 100 & 108.1 & -2.58 & Gantoeng & 0.07 & 0.04 & 0.39 & 0.23 & 20.5 & 23.7 & 168.2 & 116.4 \\
\hline 101 & 115.13 & -8.45 & Benoa, Bali & 0.71 & 0.33 & 0.25 & 0.12 & 286.4 & 354.6 & 301.1 & 276.3 \\
\hline 102 & 117.12 & -0.3 & SUngai Mariam & 0.57 & 0.31 & 0.21 & 0.16 & 203.5 & 258.6 & 305.1 & 279.3 \\
\hline 103 & 125.05 & 1.22 & Kema & 0.21 & 0.27 & 0.17 & 0.11 & 142.7 & 179.8 & 255.2 & 238.5 \\
\hline 104 & 123.03 & 0.3 & Gorontalo & 0.15 & 0.21 & 0.25 & 0.1 & 100.8 & 166.9 & 281.3 & 215.5 \\
\hline 105 & 120.06 & 0.03 & Menelili & 0.21 & 0.18 & 0.22 & 0.15 & 116.7 & 174.8 & 272.2 & 221.4 \\
\hline 106 & 120.46 & -1.22 & Poso & 0.23 & 0.23 & 0.16 & 0.12 & 113.3 & 164.5 & 262.6 & 221.8 \\
\hline 107 & 122.4 & -1.09 & Kintong & 0.3 & 0.18 & 0.26 & 0.18 & 23.5 & 108.7 & 312.7 & 265.9 \\
\hline 108 & 119.3 & -4 & Pare Pare Bay & 0.12 & 0.16 & 0.31 & 0.15 & 124.9 & 207 & 292.8 & 253 \\
\hline 109 & 129.35 & -8 & Tepa & 0.57 & 0.19 & 0.13 & 0.12 & 17.2 & 86.8 & 304.3 & 287.9 \\
\hline 110 & 131.42 & -7 & Ritabel, Larat I. & 0.6 & 0.17 & 0.23 & 0.17 & 54.5 & 102.6 & 331.7 & 317.8 \\
\hline 111 & 132.58 & -5.38 & Elat, Kai Island & 0.59 & 0.18 & 0.24 & 0.18 & 39.9 & 116.1 & 327.4 & 311.5 \\
\hline 112 & 134.14 & -5.45 & Dobo, Aroe I. & 0.61 & 0.19 & 0.28 & 0.17 & 42.4 & 121.5 & 326.1 & 306.3 \\
\hline
\end{tabular}


Etimation of Tidal Energy

\begin{tabular}{|c|c|c|c|c|c|c|c|c|c|c|c|}
\hline \multirow[t]{2}{*}{ No } & \multirow{2}{*}{$\begin{array}{l}\text { Longitude } \\
\mathrm{E}\end{array}$} & \multirow{2}{*}{$\begin{array}{r}\text { Latitude } \\
\mathrm{N}(+) / \mathrm{S}(-)\end{array}$} & \multirow[t]{2}{*}{ Station } & \multicolumn{4}{|c|}{ Amplitude (m) } & \multicolumn{4}{|c|}{ Phase (deg) } \\
\hline & & & & M2 & S2 & K1 & $\mathrm{O} 1$ & M2 & S2 & $\mathrm{K} 1$ & $\mathrm{O} 1$ \\
\hline 109 & 129.35 & -8 & Tepa & 0.57 & 0.19 & 0.13 & 0.12 & 17.2 & 86.8 & 304.3 & 287.9 \\
\hline 110 & 131.42 & -7 & Ritabel, Larat & 0.6 & 0.17 & 0.23 & 0.17 & 54.5 & 102.6 & 331.7 & 317.8 \\
\hline 111 & 132.58 & -5.38 & Elat, Kai & 0.59 & 0.18 & 0.24 & 0.18 & 39.9 & 116.1 & 327.4 & 311.5 \\
\hline 112 & 134.14 & -5.45 & Dobo, Aroe I. & 0.61 & 0.19 & 0.28 & 0.17 & 42.4 & 121.5 & 326.1 & 306.3 \\
\hline 113 & 132 & -1.42 & Waronge & 0.69 & 0.27 & 0.28 & 0.22 & 69.9 & 160 & 334.4 & 295.5 \\
\hline 114 & 131.41 & -1.3 & Karabra River & 0.55 & 0.26 & 0.27 & 0.16 & 54.5 & 140.6 & 321.7 & 305.8 \\
\hline 115 & 130.46 & -1.17 & Sailolof & 0.25 & 0.18 & 0.24 & 0.15 & 106.3 & 186.5 & 295.6 & 270.7 \\
\hline 116 & 130.55 & -1.24 & Peli Islet & 0.21 & 0.2 & 0.22 & 0.14 & 95 & 173.2 & 288.5 & 253.6 \\
\hline 117 & 117.59 & 1 & Benoa Baroe & 0.69 & 0.56 & 0.22 & 0.15 & 160.9 & 218 & 275.3 & 246.6 \\
\hline 118 & 122.2 & -3.44 & Lembo Badjo & 0.48 & 0.18 & 0.28 & 0.17 & 26.2 & 109.3 & 319 & 265.2 \\
\hline 119 & 115.15 & 5.16 & Labuan & 0.27 & 0.12 & 0.41 & 0.33 & 322.4 & 8.5 & 320.1 & 262.3 \\
\hline 120 & 116.04 & 5.59 & Jesselton & 0.24 & 0.1 & 0.37 & 0.31 & 319 & 353 & 315 & 267 \\
\hline 121 & 116.51 & 6.53 & Kudat & 0.29 & 0.15 & 0.44 & 0.25 & 317 & 359 & 313 & 264 \\
\hline 122 & 117.53 & 4.14 & Tawao & 0.76 & 0.43 & 0.19 & 0.22 & 161 & 217 & 260 & 207 \\
\hline 123 & 114.05 & -3.19 & Kahajan & 0.42 & 0.06 & 0.67 & 0.37 & 161 & 89 & 340 & 282 \\
\hline 124 & 117.3 & -0.42 & Beraoe River & 0.71 & 0.39 & 0.13 & 0.16 & 207.4 & 268 & 296.3 & 270.1 \\
\hline 125 & 117.42 & 2.55 & Bulungan R. & 0.79 & 0.51 & 0.19 & 0.14 & 169 & 216 & 273 & 244 \\
\hline 126 & 125.42 & -8.05 & Liram Island & 0.63 & 0.24 & 0.31 & 0.23 & 30 & 110 & 312 & 298 \\
\hline 127 & 106.31 & -3.08 & Dapoer Isles & 0.17 & 0.11 & 0.61 & 0.32 & 103.9 & 78 & 147.8 & 95.1 \\
\hline 128 & 108.09 & -2.4 & Telok Pering & 0.02 & 0.03 & 0.51 & 0.37 & 310.6 & 293.7 & 121.1 & 73.5 \\
\hline 129 & 107.01 & -2.52 & Tjelaka, Liat I & 0.07 & 0.05 & 0.67 & 0.38 & 81.9 & 47 & 142.3 & 78.6 \\
\hline 130 & 107.38 & -2.45 & Tanj Pandan & 0.08 & 0.07 & 0.72 & 0.42 & 96 & 55 & 154 & 93 \\
\hline 131 & 122.23 & -3.03 & Salabangka & 0.48 & 0.19 & 0.28 & 0.19 & 21.1 & 86.2 & 303.9 & 285.2 \\
\hline 132 & 135.35 & -0.51 & Korido & 0.55 & 0.23 & 0.24 & 0.15 & 194.7 & 241.8 & 201.8 & 186.9 \\
\hline 133 & 121.33 & -2.04 & Lingkoboe & 0.47 & 0.17 & 0.3 & 0.18 & 351.8 & 90.9 & 296.8 & 245 \\
\hline 134 & 115.58 & 6.01 & Gaya & 0.21 & 0.11 & 0.3 & 0.3 & 311.9 & 353.1 & 313.4 & 262.6 \\
\hline 135 & 121.36 & -4.03 & Kolaka & 0.56 & 0.16 & 0.31 & 0.21 & 5.7 & 68.8 & 291.7 & 278.9 \\
\hline 136 & 122 & -0.56 & Tobelombangi & 0.19 & 0.19 & 0.16 & 0.14 & 110 & 189 & 274 & 235 \\
\hline 137 & 127.05 & 4.43 & Karatoeng & 0.53 & 0.26 & 0.17 & 0.13 & 167 & 195 & 220 & 195 \\
\hline 138 & 140.44 & -2.33 & Hollandia Bay & 0.31 & 0.07 & 0.22 & 0.16 & 195.4 & 226.5 & 199.6 & 179.8 \\
\hline 139 & 120.14 & 5.08 & Gallo Malo C. & 0.68 & 0.38 & 0.17 & 0.15 & 165.4 & 211.5 & 263.1 & 228.3 \\
\hline 140 & 115.08 & 5 & Sapo Point & 0.32 & 0.14 & 0.41 & 0.34 & 334 & 16 & 319 & 266 \\
\hline 141 & 113.42 & 3.58 & Kuala Niah & 0.17 & 0.09 & 0.37 & 0.34 & 347 & 22 & 319 & 266 \\
\hline 142 & 135.15 & -4.28 & Aidoena & 0.49 & 0.1 & 0.37 & 0.33 & 44 & 120 & 24 & 341 \\
\hline 143 & 114.2 & -3.3 & Barito River & 0.31 & 0.07 & 0.64 & 0.31 & 135.7 & 54.3 & 326.5 & 248.2 \\
\hline 144 & 114.36 & -3.2 & Bandjermasin & 0.31 & 0.05 & 0.59 & 0.32 & 175.2 & 120.8 & 352.2 & 290 \\
\hline 145 & 117 & -5 & Lima Island & 0.08 & 0.09 & 0.3 & 0.18 & 137.4 & 221 & 287.8 & 273.6 \\
\hline
\end{tabular}


I Wayan Gede Astawa Karang, Fumihiko Nishio and Takahiro Osawa

\begin{tabular}{|c|c|c|c|c|c|c|c|c|c|c|c|}
\hline \multirow[t]{2}{*}{ No } & \multirow{2}{*}{$\begin{array}{l}\text { Longitude } \\
\text { E }\end{array}$} & \multirow{2}{*}{$\begin{array}{r}\text { Latitude } \\
\mathrm{N}(+) / \mathrm{S}(-)\end{array}$} & \multirow[t]{2}{*}{ Station } & \multicolumn{4}{|c|}{ Amplitude (m) } & \multicolumn{4}{|c|}{ Phase (deg) } \\
\hline & & & & M2 & S2 & K1 & $\mathrm{O} 1$ & M2 & S2 & K1 & $\mathrm{O} 1$ \\
\hline 146 & 131.16 & -1.32 & Kobalin River & 0.51 & 0.19 & 0.28 & 0.18 & 81 & 170 & 326 & 298 \\
\hline 147 & 136.05 & -1.11 & Sorido Lago & 0.43 & 0.12 & 0.2 & 0.14 & 219 & 253 & 221 & 192 \\
\hline 148 & 131.08 & -1.46 & Jef Joes & 0.47 & 0.18 & 0.28 & 0.18 & 74 & 162 & 326 & 301 \\
\hline 149 & 116.29 & -1.52 & Pasir River & 0.64 & 0.51 & 0.28 & 0.18 & 140 & 200 & 281 & 250 \\
\hline 150 & 109.54 & -1.12 & Soekadana & 0.16 & 0.13 & 0.66 & 0.42 & 341 & 353 & 156 & 98 \\
\hline 151 & 109.54 & -1.46 & Pawan River & 0.18 & 0.13 & 0.5 & 0.38 & 324 & 337 & 150 & 94 \\
\hline 152 & 110.44 & -2.59 & Djelai River & 0.12 & 0.03 & 0.16 & 0.1 & 215.9 & 157.5 & 334.1 & 228.8 \\
\hline 153 & 111.26 & -2.54 & Waringin $\mathrm{R}$. & 0.22 & 0.06 & 0.36 & 0.16 & 192.5 & 131.1 & 333.4 & 236.1 \\
\hline 154 & 111.48 & -3.1 & Koemai B. & 0.21 & 0.06 & 0.33 & 0.21 & 172.2 & 52.9 & 318.2 & 268 \\
\hline 155 & 112.34 & -3.25 & Pemboeang & 0.24 & 0.06 & 0.41 & 0.21 & 172.2 & 52.9 & 318.2 & 268 \\
\hline 156 & 129.43 & -4.32 & Banda Harbo & 0.57 & 0.22 & 0.29 & 0.18 & 22.9 & 98.6 & 312.1 & 286.8 \\
\hline 157 & 131.42 & -4.48 & Poeloe Tioor & 0.57 & 0.21 & 0.32 & 0.2 & 31 & 95.6 & 314.1 & 293.8 \\
\hline 158 & 130.54 & -3.53 & Geser & 0.54 & 0.18 & 0.28 & 0.19 & 23.6 & 93.2 & 323.9 & 285.6 \\
\hline 159 & 130.32 & -3.07 & Boela B. & 0.44 & 0.15 & 0.21 & 0.15 & 40.3 & 132.9 & 301.3 & 288 \\
\hline 160 & 128.24 & -2.48 & Taniwel, & 0.3 & 0.14 & 0.21 & 0.12 & 36.6 & 158.2 & 307.4 & 264.1 \\
\hline 161 & 128.11 & -3.41 & Ambon Bay & 0.47 & 0.17 & 0.29 & 0.21 & 26 & 93.6 & 315.7 & 304.3 \\
\hline 162 & 117.42 & -5.12 & P. Kalokong & 0.08 & 0.1 & 0.25 & 0.17 & 115.5 & 207.6 & 305.6 & 240.8 \\
\hline 163 & 118.23 & -5.25 & P. Dewakang & 0.11 & 0.13 & 0.21 & 0.14 & 41.1 & 190.2 & 291.9 & 262.2 \\
\hline 164 & 118.55 & -6.05 & De Bril Bank & 0.21 & 0.05 & 0.3 & 0.18 & 12 & 158.2 & 299.4 & 268.6 \\
\hline 165 & 119.24 & -5.09 & Makassar & 0.08 & 0.11 & 0.28 & 0.17 & 63.1 & 195.2 & 300.9 & 270.1 \\
\hline 166 & 108 & 4.45 & Poeloe Laoet & 0.09 & 0.04 & 0.36 & 0.18 & 55.9 & 56 & 333.3 & 268.6 \\
\hline 167 & 108.02 & 3.48 & Sedanau, Nat & 0.2 & 0.07 & 0.38 & 0.28 & 87.8 & 127.9 & 340.3 & 310.6 \\
\hline 168 & 106.52 & -6.06 & Tanjung Priok & 0.05 & 0.05 & 0.25 & 0.13 & 4.6 & 311.3 & 151.9 & 130.7 \\
\hline 169 & 124.5 & 1.3 & Menado & 0.56 & 0.35 & 0.16 & 0.16 & 158.2 & 202.3 & 261.5 & 220.7 \\
\hline 170 & 122 & -0.24 & Togian B. & 0.23 & 0.21 & 0.17 & 0.14 & 110.9 & 173 & 257.3 & 230.5 \\
\hline 171 & 113.59 & 4.35 & Kuala Baram & 0.17 & 0.08 & 0.35 & 0.3 & 335 & 10 & 319 & 269 \\
\hline 172 & 121 & 6.04 & Jolo, Jolo & 0.17 & 0.11 & 0.26 & 0.25 & 226.6 & 272.3 & 315.1 & 274.9 \\
\hline 173 & 112.44 & -6.56 & KarJamuang & 0.04 & 0.08 & 0.54 & 0.26 & 16 & 356 & 317 & 259 \\
\hline 174 & 115.15 & 5.15 & Labua Borneo & 0.28 & 0.13 & 0.39 & 0.34 & 325 & 357.3 & 315.3 & 265.1 \\
\hline
\end{tabular}

